\title{
Assessing the Impact of Emigration and Remittances on the Economic Growth in Ghana
}

\author{
Caleb Amamoo-Otoo, Xiaoying Chi \\ School of Economics and Management, Shanghai Maritime University, Shanghai, China \\ Email: ekowcaleb99@gmail.com
}

How to cite this paper: Amamoo-Otoo, C., \& Chi, X. Y. (2020). Assessing the Impact of Emigration and Remittances on the Economic Growth in Ghana. Open Journal of Business and Management, 8, 2582-2596. https://doi.org/10.4236/ojbm.2020.86160

Received: October 13, 2020

Accepted: November 16, 2020

Published: November 19, 2020

Copyright $\odot 2020$ by author(s) and Scientific Research Publishing Inc. This work is licensed under the Creative Commons Attribution International License (CC BY 4.0).

http://creativecommons.org/licenses/by/4.0/

\begin{abstract}
Workers remittances play a significant role in the lives of receiving households and beneficiaries especially in Ghana. The study employed a time series data spanning from 1990-2018, to assess the impact of Emigration and Remittances on the economic growth in Ghana. There have been contradictory findings in current empirical research on the contribution of workers' remittances to economic growth. This study discovered that, Emigration and Remittances have a negative impact on the economic growth in Ghana. Actually, most of receiving household spends most of the remitted money on consumption, conspicuous spending and debt repayment rather than investment and savings. Moreover, most remittances receiving families are counterproductive to the labor participation rate in the recipient nations since most of them become reluctant to engage themselves in any productive work as a result of income received from family members abroad, thereby reducing supply of labor and economic cycle. The regression model contains other control variables like Trade, Gross Fixed Capital Formation and Foreign Direct Investment. The main task for the government of Ghana, given the critical position of Emigration and Remittances, is to give and supply opportunities to draw more remittances sent across structured channels and to ensure their effective and efficient usage.
\end{abstract}

\section{Keywords}

Economic Growth, Regression, Altruism, Workers Remittances

\section{Introduction}

Remittance inflows resulting from emigration, establish one of the significant sources of financial resource in developing countries. In few advancing or developing countries, workers remittances constitute enormous amount of foreign exchange earnings and form more than ten percent of gross domestic product 
(World Bank, 2011). It has been stated by many scholars and researchers that remittances are known to be very practical in improving health and household welfare in developing countries (Amuedo-Dorantes et al., 2010, Combes et al., 2014, Brown, 2008). In home nations, emigration and remittances itself produce beneficial impacts. It helps to reduce poverty although it may differ in the home country's labor market circumstances. It also releases the stress from unemployment and may boost salaries.

In addition, returning migrants could contribute to financial development through investment and trade generation, transfer of know-how and technology, strengthening company networks, and returning with enhanced human capital. It should also be noted that, remittances and emigration have the potential to retard economic growth. This can happen when recipients use the remittances they receive to reduce their supply of labor to the economy (Chami et al., 2005). When it does occur, the beneficiaries who are supposed to be an integral part of the active labor force are immediately dependent on the migrant for survival. If migrants' remittances inflow causes the local currency to appreciate more, it can also destroy the country's economy, because it will disadvantage and deter exports and thus decrease business and entrepreneurial competitions in the migrants' country of origin.

Emigration and remittances have been on the rise in recent decades catching the interest of researchers and academics awakening debate on their advantages and disadvantages. Emigration and remittances can enhance and improve the well-being of the family members left behind and boost the economies of countries receiving them, but they can also create a culture of dependence in the host country, decrease labor participation, and encourage conspicuous consumption and slow economic growth. In order to formulate specific policy initiatives that will allow developing economies to get the greatest benefit from these remittances inflows, better understanding of their impacts is needed. This research seeks to assess the impact of emigration and remittances on Ghana's economic growth over the period of 1990-2018.

\section{Literature Review}

\subsection{Economic Theories for Remittances}

Although there are numerous literatures on remittances and their significance for the growth of developing countries, a well-developed, systematic theory of remittances is still missing. Nevertheless, Lucas and Stark (1985) and Stark (1991), developed groundbreaking theories of remittance, including pure theory of self-interest and pure theory of altruism.

\subsubsection{The Pure Theory of Self Interest}

The pure theory of self-interest postulates that migrants save at their destination and send money to their country of origin in an attempt to engage in investment projects such as land and property purchases and invest in the stock market or 
the money market. Such savings, which are handled by the families of migrants in their home country, help to increase the overall level of investment in the home country, leading to higher economic growth. Osili (2004), and Schrieder and Knerr (2000) observed that the more migrants follow the search for acquisition of properties, the more remittances are sent. When remittances are geared towards investment, the more the domestic economy culminates higher economic growth through the financial institution. However, the pure theory of self-interest neglected the fact that, remittances hinder efficiency and development in low-income countries, as they are readily expended on consumption that is likely to be dominated by foreign products rather than productive investment.

\subsubsection{The Pure Altruism Theory}

The theory of pure altruism further argues that the motivations behind the altruistic behavior are emotional and social and are aimed at improving the living standards of their families and at maintaining and increasing the relations between the remitters and their relatives at home (Ambrosetti, Cela, \& Fokkema, 2011). This might be because the migrant undertook his journey stemming from the prevalence of poverty back home and thus to smooth family consumption. The theory noted a positive relationship between the sum of remittances and the income of migrants, and an inverse relationship with household income in the country of origin (Osili, 2004). Nevertheless, from the findings of (Buch \& Kuckulenz, 2002), remittances are primarily used for livelihood consumption which includes food and clothing, non-productive investment, debt servicing and these expenses appear to have little positive effect on the growth of local economies. Migrants remittances are mostly committed to the needs of everyday consumption.

\subsubsection{Implicit Family Contract (Loan Repayment Theory)}

Implicit family contract (Loan Repayment) theory as noted by Poirine (1997) and Brown (1997), states that the migrant's family members either funded his emigration or his schooling abroad completely or partially, hence the duty of the migrant to pay back after a while. Hence, the migrant has a contract with the family that he has to fulfill or pay when he or she gradually settles down. However, the amount to be remitted will depend on the financial situation of the migrant abroad. Sometimes the two parties may not explicitly settle upon the pay-back and the interest rate but will be left to the parties' discretion. There is always a possibility that the migrant will not repay the loan in full, or that a dispute can occur over the correct interest rate. In some cases, if the migrants breach this agreement, this could mean refusing future family harmony, relinquishing the rights to inherit future family property or real estate, loss of value and prestige in the migrants home community or village and also loss of rights to take advantage of the community services been provided to the young and the adults in the community. 
The implicit family contract theory failed to consider the fact that, loans to family members have a tendency to be open-ended. And since both parties are not seeking agreement on repayment schedule, borrowers do not know even when to make the loan payment whilst lenders are even confused and do not know when their money will be returned to them. The ambiguity may lead to stress, as the borrower may be concerned that the lender expects payment and that the lender is concerned about when he or she will be reimbursed. Furthermore, the borrower may not grasp the urgency of repaying the loan. Without a deadline the repayment of the loan is the last concern of the borrower. The borrower does not suffer any penalties for refusing to repay the loan, such as late payments and higher interest rates. And also, the borrower has no reason to take the loan seriously or to place any pressure into repaying it without the possibility of penalties. Furthermore, the implicit family contract loan provides the family member who is borrowing the money a convenient way out of their monetary problems rather than helping them work through their issues and also the borrower can easily return when he or she needs more money creating a form of dependency culture among family members.

Figure 1 is a Theoretical Framework that shows the relationship between Emigrants and Remittances. Emigration is the act of leaving a resident country in order to settle elsewhere or another country whilst Remittances refers to transfers made by the foreign migrants to household members in their country of origin.

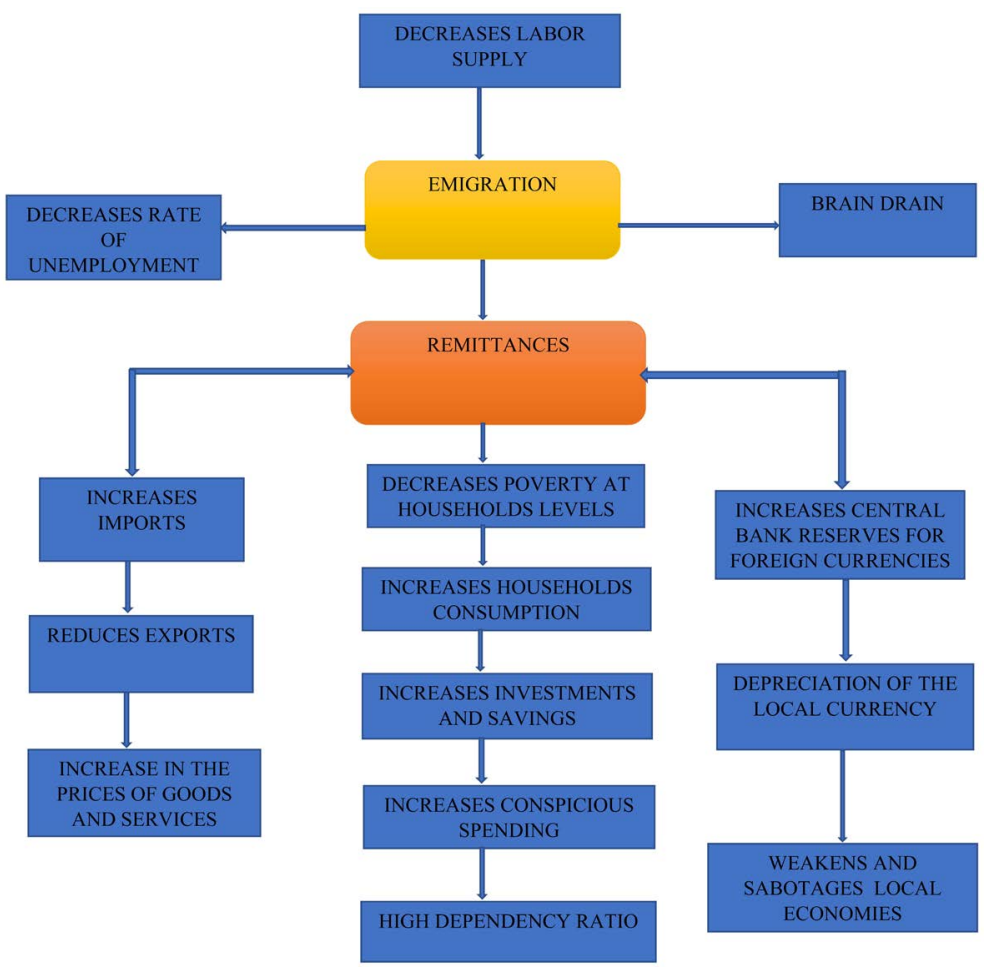

Figure 1. Theoretical framework development. source: authors. 
Emigration causes decrease in labor supply, decrease in the rate of unemployment and brain drain in the long-run. Moreover, from the table, it shows that Remittances decreases poverty at households' level, increases household's consumption, increases investments and savings but also depicts that it causes an increase in conspicuous spending and high dependency ratio at households' level.

Furthermore, the Figure depicts that, remittances increases imports, reduces exports and causes an increase in the prices of goods and services (inflation) in the long-run. In addition, remittances cause an increase in the central bank reserve for foreign currencies thereby allowing the local currency to depreciate and it also sabotages and weakens the local economies.

\subsection{Positive Effects on Emigration and Remittances}

Remittances are sufficiently massive to have larger macroeconomic consequences for some recipient countries, considering the macroeconomic variables they share. Many countries' large size of remittances compared to other external flows and to gross domestic product (GDP) suggest that the macroeconomic impact of remittances in many countries may be of imperative importance. However, though the proof on the impact of remittances on long-term growth stays indecisive, remittances tend to relieve credit constraints in economies where the financial system is underdeveloped and could boost economic growth (Ratha, 2007). For example, by creating a robust stream of foreign-exchange earnings, they can boost the creditworthiness of a country for external borrowing, and by using creative financial mechanisms, they can increase access to capital and decrease borrowing costs.

Yaseen (2012) conducted a report, using the GMM process, on the impact of remittance inflows on Middle East and North African (MENA) economic development. The empirical outcomes showed that remittances are positive and related significantly to growth. The author also discovered that there is a positive correlation between financial development and remittances. This is inconsistency with Giuliano and Ruiz-Arraz (2005) who concluded that remittances in less financially developed countries would promote growth.

Fayissa and Nsiah (2008) have performed a study using the panel data method on 37 African countries from 1980 to 2004. Empirical findings showed that remittances have a positive effect on African countries' economic development. The authors discovered that a 10 percent rise in remittances contributed to an increase of 0.3 percent in the per capita GDP in the countries under review. The authors concluded that if remittances are harnessed strategically and the prices of transfers are decreased, they would have a positive effect on African economic development.

Petkovski et al. (2011) further argues that remittances are a significant and increasing source of foreign exchange in many Southeastern European countries. In recent years, worldwide reported remittance flows have risen, driven by a va- 
riety of factors, including better data collection, more understanding of remittance growth potential, as well as concerns about money laundering and terrorist financing, lower charges and wider networks in the enterprise that supports remittance; and increase in the range of migrants and their incomes. Government initiatives to enhance access to the financial system and money transfer technologies have also helped to increase the flow of remittances and facilitate their transfer across structured channels.

\subsection{Negative Effects of Emigration and Remittances}

Spatafora (2005) recently looked at the economic responsiveness volatility of remittances for the period of 1970 using a list of 101 countries to 2003. His findings showed that remittances were negative and linked significantly to the volatility of aggregate production, consumption, and investment in the country's full sample as well as remittance-dependent economies. One shortcoming of the analysis was that it failed to account specifically for gaps in groupings of countries. Craigwell, Jackman and Moore (2008) examined the effect of remittance flows and remittance volatility in 20 small island developing countries has had on various economic volatility measures. However, no direct connection was identified between remittances and volatility in consumption. As for the stability of the remittances, the authors note fluctuations in the remittances have a significant and positive impact on the investment as well as volatility in consumption but no major impact on volatility in production. Chami et al. (2003) regressed per capita real increase on investment, change in remittances and net private capital inflows (NPCIs) as well as regional dummy variables. The authors got effective coefficients for each investment and NPCIs, however, the coefficient of remittances comes out negative. They consequently recommend that remittances are unlikely to enhance economic growth because of an ethical hazard problem (for instance, reduced labour market participation.

Feeny et al. (2014) investigated the effect of Small Island Developing States' (SIDS) remittances on economic growth. Results from variants of an empirical model indicated that whilst there is no correlation between migrants' remittances and economic growth in developing countries on average, there is a significant relation between these variables in SIDS. This finding applies to SIDS in sub-Saharan Africa and the Pacific region but not to those of Latin America and of the Caribbean.

Migrants' remittances inflows are capable of sabotaging and weakening developing countries macro-economies through surplus demand resulting in price hikes; damaging competitiveness of international export on account of real appreciation of exchange rate, and encouraging moral endangerment where labor co-operation and participation is decreased owing to excessive reliance on recipient household remittances whilst the government encouragement to enforce sound macro-economic policies regarding structural reforms, stability, prosperity and poverty reduction will be enormously shortened and reduced (Adenutsi, 
2011). Amuedo and Pozo (2004) demonstrate that remittances could minimize international competitiveness and place economic costs on the recipient countries' export sectors. Parinduri and Thangavelu (2011) point out that human capital accumulation among children can be adversely affected by the fact one mother or father leaves home to work abroad and remits money. For a panel of 113 countries over almost 30 years, Chami et al. (2005) conclude in favor of a negative link between remittances and economic growth. It is also necessary to note that there are other empirical works that assist the view that there are no positive effects of remittances on economic growth or investment, such as Spatafora (2005), who shows that remittances do not affect per capita output increase.

Chami et al. (2003) have found that remittances by migrants have a negative impact on the per-capital income growth. The study recorded three stylized facts: first, that an "important proportion and sometimes the majority" of remittances are spent on consumption; second, that a smaller proportion of remittance funds are spent on saving or investing; and thirdly, for the economy as a whole, the ways in which remittances are usually saved or spent-in housing, land and jewelry-are "not inherently productive".

\section{Methodology}

This study employed an Ordinary Least Square model to assess the correlation between the dependent variable and the independent variable and all the data for the study was taken from World Bank. The sampling size covers 28 years period, spanning from 1990-2018. Our panel data is equal, ensuring the duration for each variable is the same. The data variables used were $\beta 1$ WORREM (employee remittance received to GDP, $\beta 2$ TRD (The sum of the value of imports and exports to GDP), $\beta 3$ GCF (Gross Fixed Capital Formation as a percentage of GDP) and $\beta 4$ FDI (Foreign Direct Investment as a percentage of GDP) which are the independent variable and GDP per capita which is the dependent variable. All the data for the variables were collected from World Bank.

To assess the impact of emigration and remittances on economic growth in Ghana, this equation was derived:

$$
\text { GDP per capita }=\beta 0+\beta 1 \text { WORREM }+\beta 2 \text { TRD }+\beta 3 \text { GCM }+\beta 4 \text { FDI }
$$

Table 1 shows the selected variables, the description of each variables and their expected signs.

Table 2 depicts the statistical descriptive data utilized in the study. The mean figures of each variable are presented together with the respective standard deviations. The variable with the highest variability is GDP per capital whilst workers remittances are the variable with the lowest variability.

\section{Correlation Matrix}

A table displaying correlation coefficient between sets of variables is a Correlation matrix. In the table, every random variable is associated to each of the other 
variables in the table. This helps identify which pairs have the greatest correlation.

A variable is said to have a perfect correlation with itself, if that variable has a value of 1.000000 . Moreover, a perfect correlation between two variables is when the paired variables value is close to +1 or -1 , then the correlation is considered to be perfect. Thus, a correlation of -1 signifies a perfect negative correlation, as one variable increases, the other variable decreases whilst a correlation of $+1 \mathrm{im}$ plies a perfect positive correlation, thus as one variable increases, so does the other variable.

Table 3 shows that each of the variable has a prefect correlation with itself. GDP per capita has a strong correlation with workers remittances. Trade and FDI has a perfect correlation with GDP per capita whilst Gross fixed capital formation has a very strong correlation with GDP per capita.

Moreover, Trade has a strong correlation with workers remittances whilst Gross fixed capital formation has a very strong correlation with Trade. Workers remittances have a strong correlation with Gross fixed capital formation and FDI. And also, gross fixed capital has a strong correlation with FDI whilst Trade has a perfect correlation with FDI.

Table 1. Variables descriptions and their expected signs.

\begin{tabular}{ccc}
\hline Variables & Descriptions of Variables & Expected Signs \\
\hline Economic Growth & GDP per capita (current us) & $+/-$ \\
Workers Remittances & Workers remittances received as a percentage of GDP & $+/-$ \\
Trade & The sum of the value of imports and exports as a percentage of GDP. & + \\
Gross fixed Capital & Gross fixed capital formation as a ratio of GDP. & + \\
Foreign Direct Investment & Foreign direct investment, net outflows as a percentage of GDP & \\
\hline
\end{tabular}

Table 2. Descriptive statistics of the variables.

\begin{tabular}{cccccc}
\hline Variables & GDP per capita & Workers Remittances & Trade & Gross fixed CF & FDI \\
\hline Number of observations & 29 & 29 & 29 & 29 & 29 \\
Mean & 929.7324 & $8.39 \mathrm{e}+08$ & $1.69 \mathrm{e}+10$ & $4.98 \mathrm{e}+09$ & $1.29 \mathrm{e}+09$ \\
Standard Deviation & 696.8504 & $1.40 \mathrm{e}+09$ & $1.50 \mathrm{e}+10$ & $5.26 \mathrm{e}+09$ & $1.44 \mathrm{e}+09$ \\
\hline
\end{tabular}

Authors computation, 2020.

Table 3. The correlation matrix of the variables.

\begin{tabular}{|c|c|c|c|c|c|}
\hline Variables & GDP per capita & Workers Remittances & Trade & Gross fixed CF & FDI \\
\hline GDP per capita & 1.000000 & 0.829793 & 0.975307 & 0.934189 & 0.953888 \\
\hline Workers Remittances & 0.829793 & 1.000000 & 0.880479 & 0.868019 & 0.795386 \\
\hline Trade & 0.975307 & 0.880479 & 1.000000 & 0.905746 & 0.954831 \\
\hline Gross fixed CF & 0.934189 & 0.868019 & 0.905746 & 1.000000 & 0.843777 \\
\hline FDI & 0.953888 & 0.795386 & 0.954831 & 0.843777 & 1.000000 \\
\hline
\end{tabular}

Source: Authors computation, 2020. 


\subsection{Regression Analysis Results}

Ordinary least square model was used in the Table below to assess the correlation that exist between GDP per capita (the dependent variable) and independent variable selected (the independent variable). To evaluate the equation using multiple regression, GDP per capita (is used as dependent variable) whilst the workers remittances, trade, gross fixed capital formation and FDI were the independent variable). The ordinary least square model showed a regression that was spurious after been evaluated. This happened because some of the time series variables were non-stationary at levels.

Table 4 shows that the first regression results were spurious after been carried out.

\subsection{Augmented Dickey -Fuller Unit Root Test}

The augmented dickey fuller unit root test is used to check the null hypothesis that a unit root is there in a time series data. We utilized the schwarz information criterion to carry out the unit root test with a maximum lag of six. The $\mathrm{t}$-statistics value is anticipated to exceed 2.8 since the critical value was fixed at 2.8. The critical value was fastened at $5 \%$ for levels, $1^{\text {st }}$ and $2^{\text {nd }}$ differencing. Furthermore, a variable can be deemed as stationary if the t-statistics value exceeds the critical value which is 2.8 .

Table 5 shows the Augmented Dickey Fuller test for GDP per capita.

At $1^{\text {st }}$ differencing with a constant linear trend, the t-statistics value is -5.627281 and it exceeds the critical value set at $5 \%$ which is -2.976263 with a significant probability value of (0.0001). Hence GDP per capita is stationary.

Table 6 shows the Augmented Dickey Fuller test for Workers Remittances.

At $2^{\text {nd }}$ differencing with a constant linear trend, the t-statistics value is -13.09337 and it exceeds the critical value set at $5 \%$ which is -2.991878 with a significant probability value of $(0.0000)$. Hence workers remittances are stationary.

Table 7 shows the Augmented Dickey Fuller test for Trade.

At $1^{\text {st }}$ differencing with a constant linear trend, the t-statistics value is -3.163075 and it exceeds the critical value set at $5 \%$ which is -2.976263 with a significant probability value of (0.0337). Hence Trade is stationary.

Table 8 shows the Augmented Dickey Fuller test for Gross Fixed Capital Formation.

At level with a constant linear trend, the t-statistics value is 6.097756 and it exceeds the critical value set at $5 \%$ which is -3.004861 with a significant probability value of (1.0000). Hence Gross fixed capital formation is stationary.

Table 9 shows the Augmented Dickey Fuller Test for Foreign Direct Investment.

At $1^{\text {st }}$ differencing with a constant linear trend, the t-statistics value is -4.706985 and it exceeds the critical value set at $5 \%$ which is -2.976263 with a significant probability value of 0.0009 . Hence Foreign Direct Investment is sta- 
tionary.

Table 10 shows the Johansen Co-integration test result carried out.

Table 11 shows the Normalized Cointegration Findings.

Table 4. First regression results.

\begin{tabular}{|c|c|c|c|c|}
\hline Variable & Coefficient & Std. Error & t-Statistic & Prob. \\
\hline WORKERS_RMT & $-1.00 \mathrm{E}-07$ & $3.16 \mathrm{E}-08$ & -3.180829 & 0.0040 \\
\hline TRADE & $2.63 \mathrm{E}-08$ & $6.16 \mathrm{E}-09$ & 4.262132 & 0.0003 \\
\hline GFCF & $5.18 \mathrm{E}-08$ & $9.03 \mathrm{E}-09$ & 5.734546 & 0.0000 \\
\hline FDI & $1.19 \mathrm{E}-07$ & 4.64E-08 & 2.557829 & 0.0173 \\
\hline $\mathrm{C}$ & 159.5766 & 36.84844 & 4.330621 & 0.0002 \\
\hline R-squared & 0.982498 & \multicolumn{2}{|c|}{ Mean dependent var } & 929.7324 \\
\hline Adjusted R-squared & 0.979581 & \multicolumn{2}{|c|}{ S.D. dependent var } & 696.8504 \\
\hline S.E. of regression & 99.57662 & \multicolumn{2}{|c|}{ Akaike info criterion } & 12.19532 \\
\hline Sum squared resid & 237972.1 & \multicolumn{2}{|c|}{ Schwarz criterion } & 12.43106 \\
\hline Log likelihood & -171.8321 & \multicolumn{2}{|c|}{ Hannan-Quinn criter. } & 12.26915 \\
\hline F-statistic & 336.8170 & \multicolumn{2}{|c|}{ Durbin-Watson stat } & 1.446461 \\
\hline Prob (F-statistic) & 0.000000 & & & \\
\hline
\end{tabular}

Authors Compilation, 2020.

Table 5. Augmented dickey fuller test (gdp per capita).

\begin{tabular}{|c|c|c|c|c|c|c|}
\hline \multirow{2}{*}{$\begin{array}{c}\text { Variable } \\
\text { GDP PER CAPITA }\end{array}$} & \multicolumn{2}{|r|}{ Levels } & \multicolumn{2}{|c|}{$1^{\text {st }}$ Differencing } & \multicolumn{2}{|c|}{$2^{\text {nd }}$ Differencing } \\
\hline & Constant & Trend and Intercept & Constant & Trend and Intercept & Constant & Trend and Intercept \\
\hline T-Statistic Values & 0.181440 & -1.946884 & -5.627281 & -5.904344 & -1.024724 & -1.126402 \\
\hline Critical Values at 5\% level & -2.971853 & -3.580623 & -2.976263 & -3.587527 & -3.020686 & -3.658446 \\
\hline Critical Values & \multicolumn{2}{|r|}{-3.5} & \multicolumn{2}{|r|}{-3.5} & \multicolumn{2}{|r|}{-3.5} \\
\hline
\end{tabular}

Null Hypothesis: GDP per capita has a unit root (stationary); Exogenous: Constant, linear trend; Lag Length: 3 Max lags: 6; ADF critical values at 5\%: 2.8.

Table 6. Augmented dickey fuller test (workers remittances).

\begin{tabular}{|c|c|c|c|c|c|c|}
\hline \multirow{2}{*}{$\frac{\text { Variable }}{\text { WORKERS REMITTANCES }}$} & \multicolumn{2}{|r|}{ Levels } & \multicolumn{2}{|c|}{$1^{\text {st }}$ Differencing } & \multicolumn{2}{|c|}{$2^{\text {nd }}$ Differencing } \\
\hline & Constant & Trend and Intercept & Constant & Trend and Intercept & Constant & Trend and Intercept \\
\hline T-Statistic Values & 0.608408 & -0.026634 & -1.183061 & -2.338598 & -13.09337 & -2.882619 \\
\hline Critical Values at 5\% level & -2.998064 & -3.622033 & -2.998064 & -3.622033 & -2.991878 & -3.658446 \\
\hline Critical Values & & -3.5 & & -3.5 & & -3.5 \\
\hline
\end{tabular}

Null Hypothesis: Workers remittances has a unit root (Stationary); Exogenous: Constant, Linear trend; Lag Length: 3 Max lags: 6; ADF critical values at 5\%: 2.8 . 
Table 7. Augmented dickey fuller test (trade).

\begin{tabular}{ccccccc}
\hline Variable & \multicolumn{2}{c}{ Levels } & \multicolumn{2}{c}{$1^{\text {st }}$ Differencing } & \multicolumn{2}{c}{$2^{\text {nd }}$ Differencing } \\
\hline TRADE & Constant & Trend and Intercept & Constant & Trend and Intercept & Constant & Trend and Intercept \\
\hline T-Statistic Values & 1.514963 & -1.766416 & -3.163075 & -3.528635 & -5.144969 & -5.014202 \\
Critical Values at 5\% level & -2.971853 & -3.587527 & -2.976263 & -3.587527 & -2.991878 & -3.612199 \\
Probability & 0.9989 & 0.6927 & 0.0337 & 0.0563 & 0.0004 & 0.0026 \\
Critical Values & & -3.5 & & -3.5 & -3.5 & \\
\hline
\end{tabular}

Null Hypothesis: Trade has a unit root (Stationary); Exogenous: Constant, Linear trend; Lag Length: 3 Max lags: 6; ADF critical values at 5\%: 2.8.

Table 8. Augmented dickey fuller test (gross fixed capital formation).

\begin{tabular}{ccccccc}
\hline Variable & \multicolumn{2}{c}{ Levels } & \multicolumn{2}{c}{$1^{\text {st }}$ Differencing } & \multicolumn{2}{c}{$2^{\text {nd }}$ Differencing } \\
\hline $\begin{array}{c}\text { GROSS FIXED CAPITAL } \\
\text { FORMATION }\end{array}$ & Constant & Trend and Intercept & Constant & Trend and Intercept & Constant & Trend and Intercept \\
\hline T-Statistic Values & 6.097756 & 3.655735 & 1.180305 & -0.975135 & -3.932791 & -5.419031 \\
Critical Values at 5\% level & -3.004861 & -3.632896 & -3.012363 & -3.644963 & -3.020686 & -3.658446 \\
Probability & 1.0000 & 1.0000 & 0.9968 & 0.9263 & 0.0077 & 0.0016 \\
Critical Values & & -3.5 & & -3.5 & -3.5 & \\
\hline
\end{tabular}

Null Hypothesis: Gross Fixed Capital Formation has a unit root (Stationary); Exogenous: Constant, Linear trend; Lag Length: 3 Max lags: 6; ADF critical values at 5\%: 2.8 .

Table 9. Augmented dickey fuller test (foreign direct investment).

\begin{tabular}{ccccccc}
\hline Variable & \multicolumn{2}{c}{ Levels } & \multicolumn{2}{c}{$1^{\text {st }}$ Differencing } & \multicolumn{2}{c}{$2^{\text {nd }}$ Differencing } \\
\hline FDI & Constant & Trend and Intercept & Constant & Trend and Intercept & Constant & Trend and Intercept \\
\hline T-Statistic Values & -0.419862 & -1.676528 & -4.706985 & -4.608566 & -6.502578 & -6.434405 \\
Critical Values at 5\% level & -2.971853 & -3.580623 & -2.976263 & -3.587527 & -2.986225 & -3.603202 \\
Probability & 0.8925 & 0.7348 & 0.0009 & 0.0054 & 0.0000 & 0.0001 \\
Critical Values & & -3.5 & & -3.5 & & -3.5 \\
\hline
\end{tabular}

Null Hypothesis: Foreign Direct Investment has a unit root (Stationary); Exogenous: Constant, Linear trend; Lag Length: 3 Max lags: 6; ADF critical values at $5 \%: 2.8$.

Table 10. The johansen cointegration test results.

Sample (adjusted): 19922018

Included observations: 27 after adjustments

Trend assumption: Linear deterministic trend

Series: GDP_PCCU WORKERS_RMT TRADE GFCF FDI

Lags interval (in first differences): 1 to 1

\begin{tabular}{|c|c|c|c|c|}
\hline \multicolumn{5}{|c|}{ Unrestricted Cointegration Rank Test (Trace) } \\
\hline Hypothesized & & Trace & 0.05 & \\
\hline No. of CE(s) & Eigenvalue & Statistic & Critical Value & Prob. ${ }^{* *}$ \\
\hline None* & 0.815482 & 122.0018 & 69.81889 & 0.0000 \\
\hline At most $1^{*}$ & 0.793405 & 76.37157 & 47.85613 & 0.0000 \\
\hline At most $2 *$ & 0.614054 & 33.79265 & 29.79707 & 0.0164 \\
\hline
\end{tabular}




\section{Continued}

\begin{tabular}{|c|c|c|c|c|}
\hline At most 3 & 0.241830 & 8.087059 & 15.49471 & 0.4562 \\
\hline At most 4 & 0.022418 & 0.612184 & 3.841466 & 0.4340 \\
\hline
\end{tabular}

Trace test indicates 3 cointegrating eqn(s) at the 0.05 level

* denotes rejection of the hypothesis at the 0.05 level

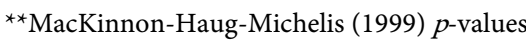

\begin{tabular}{ccccc}
\hline \multicolumn{4}{c}{ Unrestricted Cointegration Rank Test (Maximum Eigenvalue) } \\
\hline Hypothesized & & Max-Eigen & 0.05 \\
No. of CE(s) & Eigenvalue & Statistic & Critical Value & Prob. $^{* *}$ \\
None & 0.815482 & 45.63027 & 33.87687 & 0.0013 \\
At most 1 & 0.793405 & 42.57892 & 27.58434 & 0.0003 \\
At most 2 & 0.614054 & 25.70559 & 21.13162 & 0.0106 \\
At most 3 & 0.241830 & 7.474874 & 14.26460 & 0.4346 \\
At most 4 & 0.022418 & 0.612184 & 3.841466 & 0.4340
\end{tabular}

Max-eigenvalue test indicates 3 cointegrating eqn(s) at the 0.05 level

* denotes rejection of the hypothesis at the 0.05 level

${ }^{* *}$ MacKinnon-Haug-Michelis (1999) p-values

The below table shows the outcomes of the Johansen cointegration test carried out. The trace findings indicate that are five cointegration equations with statistical trace values above the critical values of 5 percent with probability values below 1 percent. Therefore, we dismiss the null statement that the variables do not have co-integration. The findings of the Maximum Eigen favor the dismissal of the null hypothesis as there are 3 cointegration equations with statistical values above the critical values of 5 percent, with probability values below 1 percent.

Table 11. Explanation of the normalized cointegration.

\begin{tabular}{|c|c|c|c|c|}
\hline \multicolumn{2}{|c|}{1 Cointegrating Equation(s): } & Log likelihood & -2488.750 & \\
\hline \multicolumn{5}{|c|}{ Normalized cointegrating coefficients (standard error in parentheses) } \\
\hline GDP_PCCU & WORKERS_RMT & TRADE & GFCF & FDI \\
\hline \multirow[t]{2}{*}{1.000000} & $9.47 \mathrm{E}-08$ & $3.71 \mathrm{E}-08$ & $-1.26 \mathrm{E}-07$ & $-4.85 \mathrm{E}-07$ \\
\hline & $(3.4 \mathrm{E}-08)$ & $(7.8 \mathrm{E}-09)$ & $(1.6 \mathrm{E}-08)$ & $(4.5 \mathrm{E}-08)$ \\
\hline \multicolumn{5}{|c|}{ Adjustment coefficients (standard error in parentheses) } \\
\hline \multirow[t]{2}{*}{ D(GDP_PCCU) } & 0.267064 & & & \\
\hline & $(0.29174)$ & & & \\
\hline \multirow[t]{2}{*}{ D(WORKERS_RMT) } & -647043.7 & & & \\
\hline & $(1393407)$ & & & \\
\hline \multirow[t]{2}{*}{$\mathrm{D}$ (TRADE) } & -8927794. & & & \\
\hline & $(3087866)$ & & & \\
\hline \multirow[t]{2}{*}{$\mathrm{D}(\mathrm{GFCF})$} & 9065266. & & & \\
\hline & $(1769012)$ & & & \\
\hline \multirow[t]{2}{*}{$\mathrm{D}(\mathrm{FDI})$} & 837304.5 & & & \\
\hline & (626938.) & & & \\
\hline
\end{tabular}


The normalized cointegration findings indicate that GDP per capita is the normalized variable whilst Workers remittances, Trade, Gross fixed capital formation and Foreign Direct Investment as the independent variable. Independent variables with negative outcomes are interpretated to positively have an impact on the normalized variable and independent variable with positive outcomes are interpretated to rather have a negative impact on the normalized variable.

Therefore, all other things held constant, the findings of this equation indicate that, workers remittances and trade have a negative impact on the normalized variable which is GDP per capita whilst gross fixed capita formation and Foreign Direct Investment rather have a positive effects or influence on the normalized variable (GDP per capita). Therefore, the null hypothesis of no co-integration in the model is absolutely in opposition to the choice of a cointegration correlation.

\section{Conclusions and Recommendations}

The aim of this study is to assess the impact of worker remittances on the economic growth in Ghana through the use of a time series data from 1990-2018. Multiple regression analysis was employed to assess the relationship between worker remittances and economic growth. In order to validate the main hypothesis in the multiple regression analysis, separate experimental test like Augmented Dickey fuller test and Johansen co-integration test, were carried out. Multiple regression analysis was carried out after utilizing and performing all these tests. The results demonstrated that worker remittance is negative and does not promote economic growth in Ghana.

Hence, the government must provide development policies that will help facilitate the flow of remittances that can allow and encourage the remittance receiving households and individuals to put the resources in effective and efficient uses, over and above just consumption.

For example, government must establish the institutional provisions needed for educating, informing and orienting prospective migrants before they emigrate in order to enhance their well-being in the host nations and promote the flow of remittances back home. In addition, the government must open-up the financial institution for easy flow of remittance that would not solely promote accountability but will additionally decrease the disappearance of valuable money when remitting using illegal channels.

This study mainly focused on assessing the impact of emigration and remittances on economic growth in Ghana; therefore, subsequent studies should explore the correlation between workers remittances and other macro-economic variables that also has a great influence on economic growth. Some of the variables did not have data available for 2019 and 2020, so the researcher limited the study to 2018 .

\section{Conflicts of Interest}

The authors declare no conflicts of interest regarding the publication of this paper. 


\section{References}

Adenutsi, E. D. (2011). Financial Development, International Migrant Remittances and Endogenous Growth in Ghana. Studies in Economics and Finance, 28, 68-89. https://doi.org/10.1108/10867371111110561

Ambrosetti, E., Cela, E., \& Fokkema, C. M. (2011). The Remittances Behaviour of the Second Generation in Europe: Altruism or Self-Interest? Ancona: Università Politecnica delle Marche, Dipartimento di Scienze Economiche e Sociali.

Amuedo-Dorantes, C., \& Pozo, S. (2004). Workers' Remittances and the Real Exchange Rate: A Paradox of Gifts. World Development, 32, 1407-1417. https://doi.org/10.1016/j.worlddev.2004.02.004

Amuedo-Dorantes, C., \& Pozo, S. (2010). Accounting for Remittance and Migration Effects on Children's Schooling. World Development, 38, 1747-1759. https://doi.org/10.1016/j.worlddev.2010.05.008

Buch, C. M., \& Kuckulenz, A. (2002). Worker Remittances and Capital Flow. Kiel: Kiel Institute for World Economic Working Paper Number 1130.

Brown, R. (1997). Estimating Remittances Functions for Pacific Island Migrants. World Development, 25, 613-626. https://doi.org/10.1016/S0305-750X(96)00122-2

Brown, R. P. (2008). Remittances and Development in the Pacific: Effects on Human Development in Fiji and Tonga. ESCAP, EGM Meeting on Migration and Development, Bangkok.

Chami, R., Fullenkamp, C., \& Jahjah, S. (2003). Are Immigrant Remittances Flows a Source of Capital for Development. IMF Working Paper (WP/03/189). https://doi.org/10.5089/9781451859638.001

Chami, R., Fullenkamp, C., \& Jahjah, S. (2005). Are Immigrant Remittance Flows a Source of Capital for Development? IMF Staff Papers, 52, 55-81.

Combes, J. L., Ebeke, C. H., Etoundi, S. M. N., \& Yogo, T. U. (2014). Are Remittances and Foreign Aid a Hedge against Food Price Shocks in Developing Countries? World Development, 54, 81-98. https://doi.org/10.1016/j.worlddev.2013.07.011

Craigwell, R., Jackman, M., \& Moore, W. (2008). Economic Volatility and Remittances: Evidence from SIDS. Central Bank of Barbados, Mimeo, February.

Feeny, S., Iamsiraroj, S., \& Mcgillivray, M. (2014). Remittances and Economic Growth: Larger Impact in Smaller Countries? The Journal of Development Studies, 50, 1055-1066. https://doi.org/10.1080/00220388.2014.895815

Fayissa, B., \& Nsiah, C. (2008). The Impact of Remittances on Economic Growth and Development in Africa. Working Papers 200802, Middle Tennessee State University, Department of Economics and Finance.

Lucas, R. E. B., \& Stark, O. (1985). Motivations to Remit: Evidence from Botswana. Journal of Political Economy, 93, 901-918. https://doi.org/10.1086/261341

Parinduri, R., \& Thangavelu, S. (2011). Impact of Remittances on Human Capital Development of Children in Indonesian Household. Singapore: National University of Singapore.

Petkovski, M., Dodeva, J., \& Georgieva, V. (2011). The Macroeconomic Effects of Remittances in Southeast Europe.

Poirine, B. (1997). A Theory of Remittances as an Implicit Family Loan Arrangement. World Development, 25, 589-611. https://doi.org/10.1016/S0305-750X(97)00121-6

Osili (2004). Migrants and Housing Investments: Theory and Evidence from Nigeria. Economic Development and Cultural Change, 52, 821-849. 
https://doi.org/10.1086/420903

Ratha, D. (2007). Leveraging Remittances for International Capital Market Access. Washington DC: World Bank.

Schrieder \& Knerr (2000). Labour Migration as a Social Security Mechanism for Smallholder Households in Sub-Saharan Africa: The Case of Cameroon. Oxford Development Studies, 28, 223-236. https://doi.org/10.1080/713688309

Spatafora, N. (2005). Worker's Remittances and Economic Development.

Stark, O. (1991). The Migration of Labour. Oxford: Basil Blackwell Ltd.

World Bank (2011). Migration and Remittances Factbook 2011: Second Edition. Washington DC: World Bank. https://openknowledge.worldbank.org/handle/10986/2522

Yaseen, H. S. (2012). The Positive and Negative Impact of Remittances and Economic Growth in MENA Countries. The Journal of International Management Studies, 7, 7-14. 